\title{
Productivity, Water Use Efficiency and Profitability of Drip Irrigated Wheat (Triticum aestivum) in Indo-Gangatic Plains of Uttarakhand, India
}

\author{
Tanmoy Bhowmik ${ }^{1}$, A.K. Bhardwaj ${ }^{2}$, T. Pandiaraj ${ }^{3}$ and Arnab Roy ${ }^{4}$ \\ ${ }^{1}$ Department of Agronomy, University of Agricultural Science, GKVK, Bengaluru, \\ Karnataka-560065, India \\ ${ }^{2}$ Department of Agronomy, G. B. Pant University of Agriculture and Technology \\ (GBPUA\&T), Pantnagar, Uttarakhand, India \\ ${ }^{3}$ Central Tasar Research and Training Institute, Piska-Nagri, Ranchi, Jharkhand, India \\ ${ }^{4}$ Department of Agricultural Economics, University of Agricultural Science, GKVK, \\ Karnataka-560065, India \\ *Corresponding author
}

A B S T R A C T

\begin{tabular}{l} 
Ke y w o r d s \\
$\begin{array}{l}\text { CPE, Drip } \\
\text { irrigation, Farmers, } \\
\text { practice, Irrigation, } \\
\text { Monetary, Yield }\end{array}$ \\
\hline Article Info \\
$\begin{array}{l}\text { Accepted: } \\
\text { 26 January } 2018 \\
\text { Available Online: } \\
\text { 10 February } 2018\end{array}$ \\
\hline
\end{tabular}

A field experiment was conducted during Rabi season of 2016-17 in G.B. Pant University of Agriculture and Technology, Pantnagar to study the effect of drip irrigation on grain yield and their attributing characters, water use efficiency and monetary benefits of wheat crop. The treatments consisted of drip irrigation with 50, 75 and $100 \% \mathrm{CPE}$ on each 2 days and 4 days interval period. Apart from drip irrigation treatments, two conventional irrigation methods were also included i.e. as absolute control and farmers' practice. These eight treatments were designed in Randomized Block Design with four replications. Results revealed that water use efficiency and water savings in all drip irrigated treatments recorded significantly higher than the farmers' method of irrigation. Wheat with drip irrigation at $100 \% \mathrm{CPE}$ on two days interval resulted in higher grain yield $\left(5825 \mathrm{~kg} \mathrm{ha}^{-1}\right)$ with less water requirement $(207.90 \mathrm{~mm})$ compared to conventionally irrigated wheat with less grain yield (4485 $\left.\mathrm{kg} \mathrm{ha}^{-1}\right)$ and high water requirement $(300 \mathrm{~mm})$. So, it is clear that drip irrigation treatments based on CPE performed better than conventionally irrigated wheat. On the basis of above results, it can be concluded that Drip irrigation at 75 or $100 \%$ $\mathrm{CPE}$ on two days interval can be a better alternative over conventionally irrigated wheat.

\section{Introduction}

Water is considered to be a scarce resource in Indian agriculture. Agriculture is the largest water user consuming about $83 \%$ of the total available water. Increasing demand for industrial and domestic water will result in reduction in water diversion to agriculture. This brings us the message that with increasing demand for food production under resource-poor situations where agriculture becomes more and more competitive, cultivation must be geared to achieve higher productivity (yield per unit land and /or water resource) in order to meet the market demand for the commodity. In this context, judicious management of all the inputs in an agricultural production system is vital. The agriculture, which depends purely on rainfall, will not be a viable venture since we cannot totally rely on the rainfall which is beyond human control. In 
India, wheat (Triticum aestivum) is the second important staple crop after rice producing 93 $\mathrm{mt}$ from $30 \mathrm{~m}$. ha area with average productivity of $2.98 \mathrm{t} / \mathrm{ha}$ (Directorate of Economics and Statistics, 2014). According to Singh et al., (2012) the demand for wheat in India by 2020 has been estimated to be between 105 to 109 million tonnes as against present day production i.e., 93 million tonnes. Wheat crop in India is grown during winter months when rains are normally scarce. It mainly depends on the supplementary irrigation for its water use. Irrational irrigation practice leads to either under or over irrigation. Therefore, to maintain the optimum soil moisture in the root zone of the wheat crop, it is important to work out an effective and economic schedule of irrigation under a given agro-climatic zone.

Micro-irrigation, especially drip irrigation system can control the rate of water application to achieve application efficiency as high as $90-100 \%$. As the entire soil surface does not get wet, weed growth is checked by drip systems. The system is also excellent for soils with higher infiltration rates. Unlike surface and sprinkler irrigation, the drip system can keep the soil water content always near the field capacity without creating any soil moisture deficit to the crop. Drip irrigation systems are designed to apply only the required amount of water. Therefore, it would minimize water losses from runoff, percolation, and seepage. This would be the crux for future green revolution and food security through water and energy security. Keeping all these points in view the present experiment was conducted to study the irrigation scheduling for better yield, water use efficiency (WUE) and monetary benefits for wheat.

\section{Materials and Methods}

The field experiment was conducted during rabi season at University Farm, G.B. Pant University of Agriculture and Technology,
Pantnagar, India located at $29^{\circ} \mathrm{N}$ latitude, $79^{0} .29^{\prime} \mathrm{E}$ longitude and at an altitude of 243.84 meters from mean sea level. During the experimental period year, the mean maximum and minimum temperature were 35.31 and $4.28^{\circ} \mathrm{C}$, respectively, mean relative humidity was maximum $93 \%$ in morning and minimum $20 \%$ in evening, total rainfall was $76.2 \mathrm{~mm}$. The soil was classified as mollisol was silty clay loam in nature high in organic carbon and available $\mathrm{P}$ and medium in $\mathrm{K}$ and low in available $\mathrm{N}$ with neutral to alkaline in reaction.

The experiment was laid out in randomized block design with four replications. The treatments were consisted of conventional and drip irrigation practices for wheat crop. A conventional irrigation practice includes wheat grown without fertilizers as absolute control $\left(\mathrm{T}_{1}\right)$ and with fertilizers as farmer's practice $\left(\mathrm{T}_{2}\right)$. Whereas, under drip irrigation method, irrigation provided at $50 \% \mathrm{CPE}$ on two days interval $\left(\mathrm{T}_{3}\right)$; at $75 \% \mathrm{CPE}$ on two days interval $\left(\mathrm{T}_{4}\right)$; at $100 \%$ CPE on two days interval $\left(\mathrm{T}_{5}\right)$; at $50 \% \mathrm{CPE}$ on four days interval $\left(\mathrm{T}_{6}\right)$; at $75 \%$ CPE on four days interval $\left(\mathrm{T}_{7}\right)$ and at $100 \%$ $\mathrm{CPE}$ on four days interval $\left(\mathrm{T}_{8}\right)$

Wheat variety WH-1124 was grown in 2016 with seed rate $100 \mathrm{~kg} \mathrm{ha}^{-1}$ at $20 \mathrm{~cm}$ row spacingwith recommended package of practices. In order to ensure ideal condition for proper germination, pre sowing irrigation was given. Irrigations were applied through drip irrigation based on daily pan evaporation values were measured with the help of USWB class ' $A$ ' open pan evaporimeter installed in the Crop Research Centre of university. While, conventional method, 5 irrigations were applied with $6 \mathrm{~cm}$ depth in each irrigation through irrigation channels at critical growth stages. The amounts of irrigation water by one lateral in different irrigation treatments were calculated as

$V=r . E_{o} \cdot K_{p a n} \cdot K_{c} \cdot A$ 
Where, V - Volume of water to be delivered by one lateral $(\mathrm{lpH}), \mathrm{E}_{\mathrm{o}}$ is USWA open pan evaporation ( $\mathrm{mm} /$ day), $\mathrm{K}_{\mathrm{pan}}$ is Pan coefficient, $\mathrm{K}_{\mathrm{c}}$ is Crop co efficient, $\mathrm{r}$ is Unit constant, $\mathrm{A}$ is Area covered by one lateral $\left(\mathrm{m}^{2}\right)$.

Then, time of operation of drip system to deliver the required volume of water per lateral as per the irrigation treatment was computed based on the formula

Volume of water to be delivered (V) By one lateral (1)

Time of operation (Hours) $==$

Emitter discharge rate $(\mathrm{lpH}) \mathrm{x}$

Number of emitters

The entire quantity of phosphorus $\left(60 \mathrm{~kg} \mathrm{ha}^{-1}\right)$ in the form of DAP and potash as MOP along with 50 percent of nitrogen were applied uniformly in the furrows as basal dose.

The remaining 50 percent of nitrogen was applied as top dressing at tillering stage as per treatments.

All the cultural operations were carried out as per recommendations.

The crop was harvested manually with the help of sickle when grains matured and straw had turned yellow and data on test weight, grain yield, straw yield and harvest index were recorded.

The sun-dried bundles were threshed and winnowed and grains obtained were weighed. The straw yield was obtained by subtracting the grain yield from the biological yield. Water use efficiency was calculated by dividing grain yield on the amount of water used. The economics was calculated based on prevailing prices of inputs and output.

The obtained data were statistically analysed by two-way Analysis of Variance (ANOVA) following the method of Gomez and Gomez (1984).

\section{Results and Discussion}

\section{Yield attributing characters}

Yield components of wheat including effective tillers $\mathrm{m}^{-2}$, number of ears $\mathrm{m}^{-2}$, number of grains ear ${ }^{-1}$, grain weight ear ${ }^{-1}$, number of spikelets $\mathrm{m}^{-2}$, and 1000 grain weight at harvest were differently affected by various irrigation methods (Table 1). Significantly higher effective tillers $\mathrm{m}^{-2}$ under drip irrigation as compared to conventional irrigation methods indicates that optimum soil moisture ensures better plant population and stand establishment of wheat. In $\mathrm{T}_{5}$ treatment had recorded higher effective tillers among different drip irrigation methods followed by $\mathrm{T}_{4}$ treatment, however, it was on par with all drip irrigation and $\mathrm{T}_{2}$ treatments. Similar results were also observed for number of grains ear ${ }^{-1}$ of wheat in this experiment. Number of grains ear ${ }^{-1}$ and grain weight ear ${ }^{1}$ are considered two important components directly related to wheat grain yield. Drip irrigation treatments brought about significant higher value of number of grains ear $^{-1}$ and grain weight ear ${ }^{-1}$ than conventional irrigation method. Among drip irrigation, the both number of grains ear ${ }^{-1}$ and grain weight ear $^{-1}$ value were gradually and significantly increased with $\mathrm{T}_{5}$ treatment followed by $\mathrm{T}_{4}$ and $\mathrm{T}_{8}$ treatments. In the present study, $\mathrm{T} 1$ treatment showed comparatively lower number of grains ear ${ }^{-1}$ and grain weight ear $^{-1}$ value of 34 and $1.2 \mathrm{~g}$, respectively.

Both drip irrigation and farmers practice treatments gave about equally significant higher number of spikelets $\mathrm{m}^{-2}$ than $T_{1}$ treatment. The $\mathrm{T}_{5}$ treatment produced significantly higher total number of spikelets $\mathrm{m}^{-2}$ over other treatments. The number of spikelets $\mathrm{m}^{-2}$ was least under $\mathrm{T}_{1}$ treatment. Irrespective of irrigation treatments, 1000 grain weight of wheat was statistically similar in all drip and farmers irrigation method over 
$\mathrm{T}_{1}$ treatment. In general, all wheat attributing characters under drip irrigation was found to be superior over farmers' practice. This might be due to uniform and adequate availability of water and better conducive rhizosphere for higher uptake of nutrients which in turn boost the growth, leading to the development of higher yield attributes through supply of more photosynthates towards the sink. These results are in close conformity with Chouhan et al., (2015).

\section{Yield characters of wheat}

The effects of irrigation method treatments on grain yield of wheat were significant for present experiment period (Table 2). There was significant difference in grain yield between drip and farmers practice treatments.

As observed that, wheat yield was higher in the $\mathrm{T}_{5}$ treatment; however, it was statistically at par with all drip irrigation method treatment except $\mathrm{T}_{6}$ treatment. Further it showing that the grain yield was higher by $29.8 \%$ in $\mathrm{T}_{5}$ treatment over farmer practice followed by $23.6 \%$ in $\mathrm{T}_{4}$ and $20.6 \%$ in $\mathrm{T}_{8}$ treatments. In the present study, both $T_{6}$ and $T_{2}$ treatments statistically produced equal grain yield of wheat. There was no significant difference in straw yield, total biological yield, harvest index and grain-straw ratio of wheat between drip and farmers practice treatments. Wheat had the highest straw and total biological yield, harvest index and grain-straw ratio in T5 treatment; it was increased by $9.79 \%$ and $17.76 \%$ in $\mathrm{T}_{5}$ treatment over farmers' method for straw yield and total biological yield, respectively.

Higher grain yield was due to the cumulative effect of improvement in growth and yield attributes. Increase in yield might be due to more irrigations providing constant wetting of root zone which might have favoured greater release of nutrients from soil. Similar findings were also reported by (Kumar et al., 2013 and Rao et al., 2014).

Table.1 Yield contributing characters of wheat as influenced by different drip irrigation treatments

\begin{tabular}{|c|c|c|c|c|c|c|}
\hline Treatments & $\begin{array}{l}\text { Total no of } \\
\text { shoots } \mathrm{m}^{-2}\end{array}$ & $\begin{array}{l}\text { No. of } \\
\text { ear } \mathrm{m}^{-2}\end{array}$ & $\begin{array}{l}\text { No. of } \\
\text { grains ear }{ }^{-1}\end{array}$ & $\begin{array}{l}\text { Grain } \\
\text { weight } \\
\text { ear }^{-1} \\
(\mathrm{~g})\end{array}$ & $\begin{array}{c}\text { Total no. } \\
\text { of } \\
\text { spikelets } \\
\text { m }^{-2}\end{array}$ & $\begin{array}{l}1000 \text { grain } \\
\text { weight }(\mathrm{g})\end{array}$ \\
\hline$T_{1}$ & 324 & 301 & 34 & 1.21 & 4480 & 35.80 \\
\hline $\mathrm{T}_{2}$ & 515 & 506 & 46 & 1.84 & 9014 & 40.07 \\
\hline $\mathrm{T}_{3}$ & 560 & 544 & 48 & 1.93 & 9962 & 40.19 \\
\hline $\mathrm{T}_{4}$ & 635 & 611 & 54 & 2.22 & 11509 & 41.22 \\
\hline $\mathrm{T}_{5}$ & 668 & 656 & 57 & 2.39 & 12892 & 41.92 \\
\hline$\overline{\mathrm{T}_{6}}$ & 526 & 512 & 47 & 1.88 & 9275 & 39.98 \\
\hline $\mathbf{T}_{7}$ & 577 & 561 & 51 & 2.08 & 10340 & 40.76 \\
\hline $\mathrm{T}_{8}$ & 612 & 597 & 53 & 2.18 & 11150 & 41.26 \\
\hline 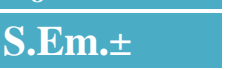 & 28 & 21 & 0.6 & 0.02 & 421 & 0.73 \\
\hline $\begin{array}{l}\text { CD } \\
(P=0.05)\end{array}$ & 84 & 64 & 1.9 & 0.05 & 1247 & 2.14 \\
\hline
\end{tabular}


Table.2 Yield characters of wheat as influenced by different drip irrigation treatments

\begin{tabular}{|l|c|c|c|c|c|}
\hline Treatments & $\begin{array}{c}\text { Grain yield } \\
\text { (kg/ha) }\end{array}$ & $\begin{array}{c}\text { Straw } \\
\text { yield } \\
\text { (kg/ha) }\end{array}$ & $\begin{array}{c}\text { Total } \\
\text { biological } \\
\text { yield (kg/ha) }\end{array}$ & $\begin{array}{c}\text { Harvest } \\
\text { Index\% }\end{array}$ & $\begin{array}{c}\text { Grain: } \\
\text { Straw } \\
\text { ratio }\end{array}$ \\
\hline $\mathrm{T}_{1}$ & 2887 & 3840 & 6727 & 43.09 & 0.75 \\
\hline $\mathrm{T}_{2}$ & 4485 & 6822 & 11307 & 39.70 & 0.66 \\
\hline $\mathrm{T}_{3}$ & 5180 & 7120 & 12300 & 42.13 & 0.72 \\
\hline $\mathrm{T}_{4}$ & 5545 & 7347 & 12892 & 43.05 & 0.75 \\
\hline $\mathrm{T}_{5}$ & 5825 & 7490 & 13315 & 43.75 & 0.78 \\
\hline $\mathrm{T}_{6}$ & 4537 & 6882 & 11420 & 39.72 & 0.66 \\
\hline $\mathrm{T}_{7}$ & 5370 & 7205 & 12575 & 42.73 & 0.74 \\
\hline $\mathrm{T}_{8}$ & 5410 & 7257 & 12667 & 42.73 & 0.74 \\
\hline $\mathrm{S} . \mathrm{Em} \pm$ & 164.54 & 271.98 & 312.24 & 1.26 & \\
\hline $\mathrm{CD}(\mathrm{P}=\mathbf{0 . 0 5}$ & 487.17 & 805.30 & 924.51 & 3.71 & \\
\hline
\end{tabular}

Table.3 Total water use ( $\mathrm{mm})$ and Water use efficiency $\left(\mathrm{kg} \mathrm{ha}^{-1} \mathrm{~mm}\right)$ as influenced by different drip irrigation treatments

\begin{tabular}{|c|c|c|c|c|c|}
\hline Treatments & $\begin{array}{l}\text { Water used } \\
\text { by irrigation } \\
(\mathrm{mm})\end{array}$ & $\begin{array}{l}\text { Effective } \\
\text { rainfall } \\
\text { (mm) }\end{array}$ & $\begin{array}{c}\text { Total water } \\
\text { used } \\
\text { (mm) }\end{array}$ & $\begin{array}{c}\text { Water } \\
\text { saving } \\
(\%)\end{array}$ & $\begin{array}{r}\text { WUE } \\
(\mathrm{kg} \mathrm{ha} \\
\left.{ }^{1} \mathrm{~mm}\right)\end{array}$ \\
\hline $\mathrm{T}_{1}$ & 300 & 38.1 & 338.1 & - & 8.54 \\
\hline$T_{2}$ & 300 & 38.1 & 338.1 & - & 13.26 \\
\hline $\mathbf{T}_{\mathbf{3}}$ & 103.95 & 38.1 & 142.05 & 57.98 & 36.47 \\
\hline $\mathbf{T}_{4}$ & 155.86 & 38.1 & 193.96 & 42.63 & 28.59 \\
\hline$T_{5}$ & 207.90 & 38.1 & 246 & 27.24 & 23.68 \\
\hline$T_{6}$ & 100.15 & 38.1 & 138.25 & 59.1 & 32.82 \\
\hline$T_{7}$ & 150.15 & 38.1 & 188.25 & 44.32 & 28.53 \\
\hline$T_{8}$ & 200.3 & 38.1 & 238.4 & 29.49 & 22.69 \\
\hline S.Em. \pm & & & & - & 0.79 \\
\hline $\mathrm{CD}(\mathrm{P}=0.05)$ & & & & - & 2.33 \\
\hline
\end{tabular}

Table.4 Economic analysis of wheat as influenced by different drip irrigation treatments

\begin{tabular}{|l|c|c|c|c|}
\hline Treatments & $\begin{array}{c}\text { Cost of cultivation } \\
\text { in ₹/ha }\end{array}$ & $\begin{array}{c}\text { Gross return } \\
\text { in ₹ /ha }\end{array}$ & $\begin{array}{c}\text { Net return } \\
\text { in ₹ /ha }\end{array}$ & $\begin{array}{c}\text { B:C } \\
\text { ratio }\end{array}$ \\
\hline $\mathrm{T}_{1}$ & 17100 & 67811 & 50711 & 2.96 \\
\hline $\mathrm{T}_{2}$ & 20690 & 123103 & 92404 & 3.01 \\
\hline $\mathrm{T}_{3}$ & 27804 & 122690 & 94886 & 3.41 \\
\hline $\mathrm{T}_{4}$ & 28454 & 130098 & 101644 & 3.57 \\
\hline $\mathrm{T}_{5}$ & 29104 & 135642 & 106538 & 3.66 \\
\hline $\mathrm{T}_{6}$ & 27767 & 110375 & 82608 & 2.97 \\
\hline $\mathrm{T}_{7}$ & 28392 & 126397 & 98005 & 3.45 \\
\hline $\mathrm{T}_{8}$ & 29017 & 127331 & 98314 & 3.39 \\
\hline
\end{tabular}




\section{Total water use and Water Use Efficiency} (WUE)

Total water use as irrigation water during the whole crop growing season ranged from 100.5 $\mathrm{mm}$ to $300 \mathrm{~mm}$ in different treatments (Table $3)$. The total water used inclusive of effective rainfall in $\mathrm{T}_{1}$ and $\mathrm{T}_{2}$ treatments with recommend irrigations during critical growth stages of crop was $338.1 \mathrm{~mm}$ whereas drip irrigation treatments varied from 138.25 to $246 \mathrm{~mm}$. Among the drip irrigation treatments, minimum water used $(138.25 \mathrm{~mm})$ was recorded in $\mathrm{T}_{6}$ treatment which was closely followed by 142.05 in $\mathrm{T}_{3}$ treatment. Highest water use i.e. $246 \mathrm{~mm}$ was recorded with $\mathrm{T}_{5}$ treatment. This resulted in saving of water which ranged from $27.2 \%$ with $\mathrm{T}_{5}$ to $59.1 \%$ with $\mathrm{T}_{6}$ under different treatments. The drip irrigation methods showed less water requirement due to restriction of water loss through evaporation from large amount of ground, conveyance losses resulted in maximum water use by crops. WUE $\mathrm{kg} \mathrm{ha}^{-1}$ $\mathrm{mm}$ was significantly influenced by different treatments. The supply of irrigation water in $T_{2}$ treatment was found to be significantly lower WUE (13.26\%) and $\mathrm{T}_{3}$ treatment showed higher WUE $(36.47 \%)$ was found with i.e. drip irrigation with $50 \% \mathrm{CPE}$ at two days interval. The increased WUE observed under drip irrigation was due to increase in grain yield and reduced water consumption compared to farmers' practice. Through drip irrigation method water and nutrients to the plant can be applied very efficiently to the effective root zones of the plants. Drip irrigation system had minimum water requirement as the loss of water is minimum in this process Vanitha (2008).

\section{Monetary benefits}

In our study, the total cost of cultivation for raising wheat crop ranged from $₹ 17100 \mathrm{ha}^{-1}$ in $\mathrm{T}_{1}$ treatment and ₹ $20690 \mathrm{ha}^{-1}$ in $\mathrm{T}_{2}$ to highest ₹ $29100 \mathrm{ha}^{-1}$ in $\mathrm{T}_{5}$ treatment. Consequent to the influence of treatments and variation in yield, the gross return also varied within the treatments. The higher gross return ₹ 135642 $\mathrm{ha}^{-1}$ was obtained from $\mathrm{T}_{5}$ treatment which is closely followed by $\mathrm{T}_{4}$ treatment (₹ 130098 $\left.\mathrm{ha}^{-1}\right)$. Gross return in conventional wheat with recommended irrigation and fertilizers was ₹ $123103 \mathrm{ha}^{-1}$. The net return varied ₹ $50711 \mathrm{ha}^{-}$ ${ }^{1}$ in $\mathrm{T}_{1}$ treatment to ₹ 106538 in $\mathrm{T}_{5}$ treatment.

The net return with $\mathrm{T}_{2}$ treatment was ₹ 92404 . Among the drip irrigation treatments, the lower net return $₹ 82608$ was found in treatment $\mathrm{T}_{6}$. In case of $\mathrm{B}$ : $\mathrm{C}$ ratio among the drip irrigated treatments, ranged from 2.97 to 3.66. The B: C ratio of $T_{2}$ treatment was showed 3.01 and $T_{5}$ treatment had record higher $\mathrm{B}: \mathrm{C}$ ratio.

Both net return and B: C ratio had increased due to the high increase in grain yield which is the results of adequate water supply and nutrient availability to the root zone area of the crop under drip irrigation system Ashoka et al., (2004) (Table 4).

Based on the results obtained from the study conducted, it can be concluded that drip irrigation was found profitable for getting higher yield and economic returns over conventional method. Water supply with $75 \%$ or $100 \%$ CPE through drip irrigation on two days interval is better in terms of water saving along with better yield, net realization and highest water use efficiency as it saves $43 \%$ water and gives $29.8 \%$ higher yield and $15.3 \%$ higher net returns over conventional method of irrigation.

\section{Acknowledgements}

Special thanks to GBPUA\&T, Pantnagar and Jain Irrigation Systems Ltd. Jalgaon, Maharashtra for providing all the facilities for conducting the experiment.

\section{References}

Abdullah, Pawar, D.D., Kale, K.D. and Dingre, S. K. 2015. Water and nutrient use efficiency of wheat under drip irrigation. Agriculture for Sustainable Development 2(1):1-5.

Ashoka, H.R. and Shashidhara, G.B. 2004. Effect of Split application of Nitrogen and Potassium on Growth, Yield and Quality 
of red Chilli under Drip Irrigation System. Department of Agronomy, College of Agriculture, Dharwad, 126 p.

Chouhan S.S., Awasthi M.K. and Nema RK. Studies on water productivity and yield responses of wheat based on drip irrigation systems in clay loam soil. Indian Journal of Science and Technology. 2015; 8(7):650-654.

Goel, A.C., Vijaykumar and Dhindsa, J.P.S. 2005. Feasibility of drip irrigation in sugarcane at Haryana, pp-4-9. Proc. Proc. Nation. Sem. Relevance of Micro irrigation in Sugarcane, VSI Pune, Maharashtra, India, pp. 9-10

Gomez, K.A. and Gomez, A.A. (1984). Statistical procedures for agricultural research. (2nd Ed.) John Wiley and Sons, New York, USA. 680 p.

Kumar, B.R., Rao. P.V., Ramulu, V. and Avilkumar, K. 2013. Drip irrigation schedule for castor based on pan evaporation. Journal of Research, ANGRAU. 41(2):149-152.

Li, Y.R. and Yong, 1993. The contents of ten nutritional elements in leaves of nine sugarcane genotypes. Sugar cane 6:10-12.

Mattas, K.K., Uppal, R.S. and Singh, R.P. 2011. Effect of Varieties and Nitrogen Management on the Growth, Yield and Nitrogen Uptake of Durum Wheat. Research Journal of Agricultural Sciences. 2: $376-380$.

Patil, G.D., Yelwande, A.J. and Chaudhari, R.D., 2001, Nitrogen fertilization to sugarcane: Prospects and retrospect, $J$. Maharashtra Agric. Univ., 26(1-3): 156158.
Pawar, D.D., Dingre, S.K., Shinde, M.G. and Kaore, S.V. 2013. Drip fertigation for Higher Crop Productivity. Research Book No. MPKV/ Res.Pub. No. 99/2013, MPKV, Rahuri-413 722, Maharashtra, India.

Rao, P.V., Rao, P.R. and Ramanjanayulu A.V. 2014. Micro irrigation technique for improved and sustainable crop production. Advance in Agro-technology (eds.) -Rodrigaez, $\mathrm{Hg} \mathrm{NC}$ Sarkar Ramajan R. Mayti, Published by Pushpa Publishing House, Kolkata, India. 166 202.

Shedeed, Shaymaa. I., Zaghloul, Sahar M., and Yassen A. A. 2009. Effect of Method and Rate of Fertilizer Application under Drip Irrigation on Yield and Nutrient Uptake by Tomato. Ozean Journal of Applied Sciences. 2 (2): 139-147.

Singh, L., Singh, C.M. and Singh, G.R. 2012. Response of bed planted wheat (Tritcum aestivum L.) under the different moisture regime on water use and its efficiency. Journal of Chemical and Pharmaceutical Research. 4(11): 4941-4945.

Vanitha, K 2008. Drip fertigation and its physiological impact in aerobic rice (Oryza stiva L.) MSc. (Ag.)Thesis submitted to Tamil Nadu Agricultural Coimbatore 641003 India. p250

Veeranna, H.K., Abdul K, and Sujith G.M. 2001. Effect of fertigation and irrigation methods on yield, water and fertilizer use efficiencies in chilli (Capsicum annum L.). South Indian Hort. 49: 1010-104.

\section{How to cite this article:}

Tanmoy Bhowmik, A.K. Bhardwaj, T. Pandiaraj and Arnab Roy. 2018. Productivity, Water Use Efficiency and Profitability of Drip Irrigated Wheat (Triticum aestivum) in Indo-Gangatic Plains of Uttarakhand, India. Int.J.Curr.Microbiol.App.Sci. 7(02): 3185-3191. doi: https://doi.org/10.20546/ijcmas.2018.702.383 